\title{
PENERAPAN PROGRAM CROCODILE PHYSICS SEBAGAI MEDIA PEMBELAJARAN DALAM UPAYA MENINGKATKAN PEMAHAMAN KONSEP FISIKA SISWA
}

\section{THE APPLICATION OF CROCODILE PHYSICS PROGRAM AS A LEARNING MEDIA IN AN EFFORT TO IMPROVE UNDERSTANDING OF STUDENTS PHYSIC CONCEPTS}

\author{
Abdi Novianto ${ }^{1}$, Nirva Diana ${ }^{2}$ \\ ${ }^{1}$ Prodi Pendidikan Fisika Fakultas Tarbiyah dan Keguruan Universitas Islam Negeri Raden Intan Lampung \\ ${ }^{2}$ Program Pascasarjana Universitas Islam Negeri Raden Intan Lampung \\ 1E-mail: abdinovianto1@gmail.com
}

Diterima: 02 Januari 2019. Disetujui: 03 Februari 2019. Dipublikasikan: 29 Maret 2019

\begin{abstract}
Research In this journal aims to find out the increasing students in understanding the conception of physics through the help of media Crocodile Physics programs. The form of research used in this study is Action Research. The population in this study amounted to 69 people consisting of 37 students in class VIII of SMP 1 Bandarlampung and 32 students in 32 students of class VIII A of SMP 25 Bandarlampung. To measure the students 'understanding of the concept, there were 3 cycles of tests with multiple choice questions 20 questions in each cycle. The results showed an increase in students' understanding of physics concepts seen from the percentage of learning outcomes completeness. Cycle I percentage of completeness in class VIII I is $40.54 \%$, cycle II is 51.35 and in cycle III is $83.78 \%$. Cycle I percentage of completeness in class VIII A is $18.75 \%$, cycle II is $43.24 \%$ then in cycle III is $81.25 \%$. Through the results of the analysis and discussion, it can be concluded that the use of the Crocodile Physics program is able to increase understanding of the concept of physics.
\end{abstract}

Keywords: crocodile physics, concept understanding, learning media

\begin{abstract}
Abstrak:Penelitian Pada jurnal ini memilikitujuan untuk mengetahui meningkatnya siswa dalam memahami konsepsi fisika melalui bantuan media programCrocodile Physics. Bentuk penelitian yang digunakanpada penelitian ini adalah Action Research. Populasi dalam penelitian ini berjumlah 69 orang terdiri dari 37 peserta didik kelas VIII SMPN 1 Bandarlampung dan 32 peserta didik 32 peserta didik kelas VIII A SMPN 25 Bandarlampung. Untuk mengukur pemahaman konsep siswa dilakukan test sebanyak 3 siklus dengan soal pilihan ganda 20 soal dimasing-masing siklus.Hasil penelitian menunjukkan peningkatan pemahaman konsep fisika siswa di lihat dari presentase ketuntasan hasil belajar. Siklus I presentase ketuntasan dikelas VIII I sebesar 40,54 \%, siklus II sebesar 51,35 dan pada siklus III sebesar $83,78 \%$. Siklus I presentase ketuntasan dikelas VIII A adalah 18,75\%, siklus II adalah 43,24 \% kemudian pada siklus III adalah 81,25\%. Melalui hasil analisis dan pembahasan dapat menyimpulkan untuk penggunaan program Crocodile Physics mampu dalam meningkatnya pemahaman konsep fisika.
\end{abstract}

(C) 2018 Unit Riset dan Publikasi Ilmiah FTK UIN Raden Intan Lampung

Kata Kunci: crocodile physics, pemahaman konsep, media pembelajaran

\section{PENDAHULUAN}

Pendidikan adalah salah satu bagian indikator dalam mernentukan arah kemajuan suatu negara (Rofik \& Basuki, 2015), sehingga pendidikan dapat digunakan sebagai salah satu aspek pengukur kemajuan bangsa (Yuberti, 2015).Pendidikan memiliki ciri khas dan identik dengan kegiatan belajar mengajar dan segala aspek yang mempengaruhi didalamnya.Untuk mencapai tujuan 
pembelajaran, maka proses belajar mengajar tersebut harus dilakukan secara optimal dan maksimal. Proses belajar mengajar adalah inti dari proses dalam pendidikan (Wajdi, 2015)berhasil atau tidaknya proses belajar mengajar tersebut membutuhkan dukungan dari guru, sekolah dan peserta didik (Komikesari, 2016).Berlangsungnya proses pembelajaran yang baik akan berdampak pada tercapainya hasil belajar peserta didik.

Berdasarkan hasil prapenelitian yang peneliti lakukan di SMP Negeri 1 Bandarlampung dan SMP Negeri 25 Bandarlampung khususnya kelas VIII pada mata pelajaran fisika didapatkan hasil presentase nilai ketuntasan belajar peserta didik di SMP N 1 Bandarlampung dari 37 peserta didik kelas VIII 1, hanya ada 5 peserta yang mendapat nilai diatas kriteria ketuntasan minimal (sebesar 80) yang artinya presentase ketercapaiannya sebesar $14 \%$, dan 32 peserta didik lainnya mendapat nilai dibawah kriteria ketuntasan minimal dengan besarnya presentase mencapai $86 \%$, kemudian di SMPN 25 Bandarlampung dari 32 peserta didik kelas VIII A, hanya ada 12 peserta mendapat nilai diatas kriteria ketuntasan minimal (sebesar 75) berarti presentase ketercapaiannya sebesar $37,5 \%$ dan 20 peserta didik lainnya mendapat nilai dibawah kriteria ketuntasan minimal dengan besarnya presentase mencapai $62,5 \%$. Datatersebut menunjukkanbahwa hasil belajar peserta didik belum tercapai.

Teori belajar menyatakan belum tercapainya hasil belajar peserta dipengaruhi oleh beberapa faktor antara lain rendahnya pemahaman konsep peserta didik, rendahnya motivasi belajar peserta didik, ruang kelas yang minim, dan kurang kondusifmya peserta didik dalam pembelajaran. Untuk memastikan faktor utama penyebab rendahnya hasil belajar tersebut, peneliti melakukan wawancara dengan beberapa guru mata pelajaran fisika. Informasi yang peneliti dapatkan adalah faktor utama rendahnya hasil belajar adalah pemahaman konsep peserta didik yang masih rendah. Faktor ini dipertegas dalam pemberian tes soal pada peserta didik.

Selain itu berdasarkan hasil observasi yang peneliti lakukan disekolah tersebut, peneliti melihat bahwa dalam pelaksanaaan kegiatan pembelajaran yang berlangsung disekolah tersebut menunjukkan kinerja guru yang masih kurang kreatif dalam proses belajar mengajar, padahal sarana dan prasarana dikelas sudah tergolong baik dengan adanya ketersediaan LCD, AC dan alat pendukung lainnya dalam menunjang proses pembelajaran. Oleh karena itu perlu adanya kreativitas guru untuk membangun proses belajar mengajar yang menarik sehingga dalam proses pembelajaran peserta didik tidak bosan.

Salah satu cara yang dapat dilakukan untuk membangun suasana belajar yang menarik yaitu dengan menggunakan media pembelajaran dalam proses belajar mengajar. Media pembelajaran merupakan sebuah alat yang digunakan sebagai perantara untuk menyampaikan isi pelajaran dalam proses belajar guna memahami materi ajar yang disampaikan oleh guru(Asyhari \& Silvia, 2016).

Crocodile Physics merupakan salah satumedia pembelajaran berbasis komputer dengan model simulasi(Gumrowi, 2017). Program ini menyediakan mini laboratorium untuk mata pelajaran fisika pada pendidikan menengah yang didalam program tersebut terdapat bebrapa materi kefisikaan berupa dinamika, kinetika, energi, gelombang, optik, dan listrik. Dengan menerapkan penggunaan media pembelajaran ini diharapkan dapat membantu meningkatkan pemahaman konsep fisika peserta didik yang akan berdampak pada meningkatnya hasil belajar peserta didik. 


\section{LANDASAN TEORI}

\section{A.Crocodile Physics}

Media pembelajaran Crocodile Physicsmerupakan sebuah program komputer yang dibuat oleh crocodile company yang didalamnya menyediakan sebuah lingkungan laboratorium untuk mata pelajaran khususnya fisika pada pendidikan menengah yang meliputi dinamika, kinetika, energi, gelombang, optik, dan listrik.(Santoso, 2013) Pembelajaran menggunakan program ini dikaitkan dengan menunjukkan bentuk komponen nyatanya, sehinga siswa nantinya dapat mengetahui bentuk dan kegunaan komponen yang di ujicobakan. Media pembelajaranCrocodile Physics meruapakan media pembelajaran berbentuk model simulasi ini memiliki tujuan memberikan sebuah pengalaman belajar yang lebih mendalam.

Bagian nyata tersebut ditampilkan melalui penciptaan tiruan-tiruan bentuk dalam kehidupan sehari-hari yang mendekati suasana yang sebenarnya. Program Crocodile Physics ini dapat digunakan sebelum melakukan suatu percobaan nyata dalam laboratorium dengan membuat simulasi bagaimana bentukkomponen nyatanya.

Media berbentuk program simulasi ini sangatlah mendukung para siswa dalam melakukan percobaan terutama elektronika karena dengan media ini bentuk dan alur rangkaian dalam percobaan dapat dibuat kemudian diaplikasikan sesuai dengan penggunaan alat yang sebenarnya.

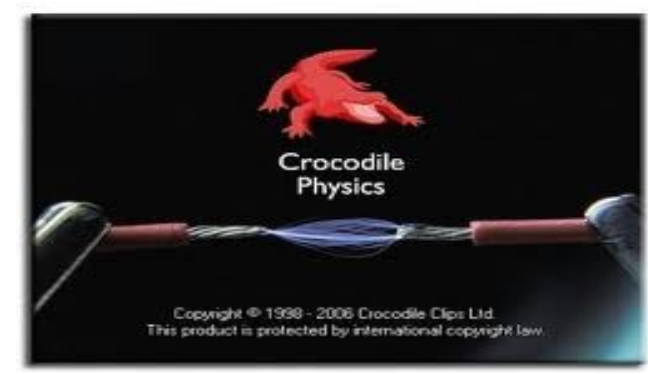

Gambar 1 Tampilan menu utama media pembelajaran Crocodile Physics.

\section{B.Pemahaman Konsep}

Ilmu fisika tidak terlepas dari materimateri, pengetahuan dan pemahaman konsep fisikanya, ilmu fisika juga tidak dapat lepas dari prediksi adanya terjadinya kesalahan konsep pada siswa karena banyak konsepsi fisika bersifat tak dapat terlihat indradan interaksinya akan menghasilkan medan tidak sentuh, akan tetapi efeknya bersifat nyata dan dapat dirasakan kita.(Mursalin, 2014)

Anderson dan Krathwohl menjelaskan 7 proses dalam fungsi kognitif untuk kategori pemahaman yang meliputi :menafsirkan,mencontohkan,mengklasifik asikan,merangkum,inferensi,membanding kan dan menjelaskan.

\section{a. Menafsirkan (interpreting)}

Indikator dalam penafsiran tercapainya apabila siswa mampu mengubah informasi dari satu bentuk ke bentuk lainnya, seperti mengubah katakata atau konsep menjadi suatu kesamaan, mengubah kata ke bentuk gambar, grafik, dan begitupun sebaliknya.

\section{b. Mencontohkan (exemplifying)}

Proses kognitif mencontohkan terjadi ketika siswa mampu memberikan sebuah contoh tentang konsep atau prinsip secara umum. Misalnya mencontohkan bisa juga berarti mengilustrasikan dan memberi contoh terhadap konsep yang telah dipelajari sebelumnya.

\section{c. Mengklasifikasikan (classifying)}

Mengklasifikasikan bisa juga disebut sebagai pengelompokan atau mengkategorikan. Indikasi dalam tercapainya sebuah proses kognitif mengklasifikasikan terjadi ketika siswa mampu untuk mengetahui sesuatu seperti contoh maupun peristiwa termasuk ke dalam suatu kategori tertentu yang ada, seperti konsep, prinsip ataupun hukum tertentu.

\section{d. Merangkum (summarizing)}

Merangkum juga bisa disebut sebagai kegiatan menggeneralisasikan dan mengabstraksi sebuah pembelajaran. Siswa dianggap mampu untuk 
merangkum ketika ia mampu untuk menyampaikan satu atau lebih kalimat yang dipresentasikannya informasi yang didapat atau mengabstraksikan sebuah tema-tema tertentu.

\section{e. Menarik Inferensi (inferring)}

Proses kognitif menarik sebuah inferensi dalam penyertaan proses penemuan sebuah pola dalam berbagai contoh yang ada. Menarik inferrensi ini cukup sama dengan kegiatan kesimpulan. Siswa mampu menarik inferensi ketika ia dapat mengabstraksi konsep atau prinsip yang menjelaskan contoh-contoh atau fenomena dengan mengamati ciri-cirinya kemudian dapat menarik hubungan diantara ciri-ciri dari rangkaian contohcontoh ataupun fenomena tersebut.

\section{f. Membandingkan(comparing)}

Perbandingan disebut juga dengan nama lain mengontraskan, memetakan dan mencocokkan. Proses ini membandingkan denganterlibatnya proses pendeteksiankesamaandan perbedaan antarkedua atau lebih objek, peristiwa, gagasan, masalah, atau situasi, seperti dalam bagaimana sebuah peristiwa terkenal menyerupai sebuah peristiwa yang kurang begitu terkenal. Membandingkan dapat berupa pencarian korespondensi ataupun pasangan satu-satu sebuah objek.

\section{g. Menjelaskan(explaining)}

Penjelasandapat juga dengan membuat sebuah model. Proses ini menjelaskan berlangsungnyapada saat siswa mampu membuat dan mengaplikasikan model sebab-akibat dalamsystem (R.K, 2010).

Faktor kuat rendahnya pemahaman konsep adalah siswa tidak diberikan praktek yang mendalam dalam menyelesaikan sebuah masalah pembelajaran pada masa lalu. Siswa menjadi tidak terbiasa dalam menghubungkan sebuah pengetahuan yang baru didapat. Siswa juga sukar dalam memilah-milah pengetahuan yang diperlukan dalam sebuah operasi pemecahan masalah pembelajaran. Sehingga siswa mengalami kesulitan dalam memahami konsep yang telah diajarkan(Sadiqin, Santoso, \& Sholahuddin, 2017).

\section{METODE PENELITIAN}

\section{Jenis Penelitian}

Bentuk penelitian yang diterapkanpada penelitian ini merupakan penelitian tindakan (action research). Action researchmerupakan penelitian yang dilakukan oleh guru untuk diri mereka sendiri (Mills, 2003) dilaksanakannya dapat memberikan cara tertentu dalam melihat ataupun meneliti keberlangsunganproses pembelajaran sudah tepat dengan yang seharusnya atau tidak (Coghlan \& Brannick, 2002)dimana penelitian ini dilaksanakan tanpa mengubah sistem pelaksanaan yang ada didalam kelas. Penelitian ini merupakan penelitian tindakan yang mencakup dari peneliti dan juga peserta didik dalam upaya meningkatkan pahamnya konsepsi fisika siswa berbantupenggunaan media berupa programCrocodile Physics.

Mengingat penelitian ini adalah penelitian tindakan, untuk mendapatkan hasil yang seoptimal mungkin maka diadakan dengan cara berulang-ulang untuk mendapatkan tujuan yang dicapai. Peneliti menargetkan bahwa rata-rata hasil nilai dalam pelajaran fisika adalah 80 dan peneliti menargetkan maksimal 3 kali siklus untuk mencapai target tersebut,apabila penelitian belum mencapai target yang diinginkan, maka pelaksanaan penelitian dicukupkan mengingat waktu yang terbatas. Dengan menggunakan media pembelajaran Crocodile Physicsakan dilihat sejauh mana keefektifan pembelajaran ini berdampak pada pemahaman konsep fisika siswa. Penelitian ini tidak dilakukan sendiri oleh peneliti melainkan bekerjasama dengan guru pelajaran fisika kelas VIII 1 dan VIII A. 
Penelitian tindakan merupakan cara dalam memecahkan sebuah masalah yang diawali dari perencanaan, pelaksanaan, mengumpulkan data (observasi), menganalisis data atau informasi untuk pemusatan dan melihat kelebihan ataupun kelemahan tindakan tersebut (refleksi)(Madya, 2011).

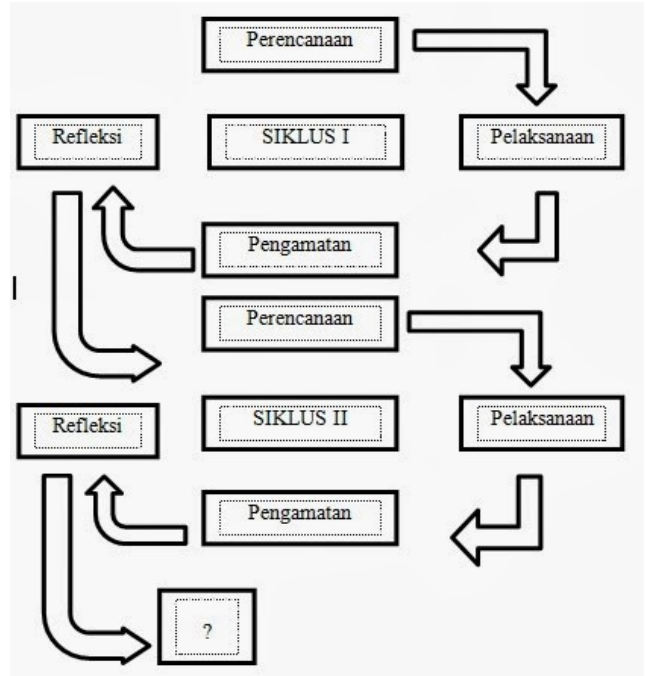

Gambar 2 Siklus penelitian tindakan

\section{Teknik Analisis Data}

Deperolehnya data oleh peneliti melalui caraterkumpulnya data dari sebuahtujuan penelitian, maka selanjutnya adalah menganalisa data sebagai berikut:

\section{a. $N_{\text {Gain }}$}

Data yang diterapkanpada penelitian kuantitatif ini diperoleh dari hasilpretest dan Posttesttingkat kemampuan belajar fisika.(Lutfiyah, 2011)

Kemudian dalamperhitungsn data tersebut digunakan dalam perhitungan $N$ Gain. Gainmerupakan selisih antara nilai pretest, posttest, dan juga digunakan dalam menghindari bias ketika penelitian dengan menggunakan rumus sebagai berikut:

$$
N-\text { Gain }=\frac{\text { skorposttest }- \text { skorpretest }}{\text { skorideal }- \text { skorpretest }}
$$

Perolehan dalam skor gain ternormalisasi terdapat tiga kelompok sebagai berikut:
Tabel 1. Kategori nilai N-gain

\begin{tabular}{cc}
\hline Kategori Nilai N-gain & Kelompok \\
N-gain $>0,70$ & tinggi \\
$0,30 \leq \mathrm{N}$-gain $\leq 0,70$ & Sedang \\
$\mathrm{N}$-gain $<0,30$ & Rendah \\
\hline
\end{tabular}

\section{b. Uji Normalitas}

Uji normalitas dapat digunakandalam memahami sampel yang diteliti terdistribusi normal atau tidak.Uji kenormalan yang dilakukan adalah uji Liliefors.

\section{HASIL DAN PEMBAHASAN 1.Siklus I}

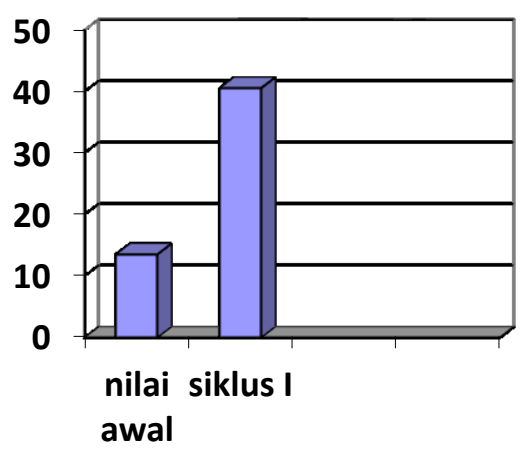

Gambar 3.Presentase ketuntasan hasil peserta didik

Berdasarkan tabel kemudian gambar grafik di atas menunjukkan bahwa presentase keberhasilan pencapaian mengalami peningkatan. Pada tes yang dilakukan sebelum tindakan diberikan (pretest), dari 37 peserta didik yang mengikuti, hanya ada 5 peserta didik yang mencapai ketuntasan belajar. Sedangkan setelah diterapkan media pembelajaran crorodile phyiscs pada siklus I, dari 37 orang yang mengikuti tes akhir siklus I yang berupa terdapat 15 orang atau 40,54 $\%$ peserta didik yang mencapai ketuntasan belajar. Dengan demikian setelah dilakukan tindakan siklus I, hasil belajar peserta didik mengalami peningkatan sebesar $27,03 \%$. 


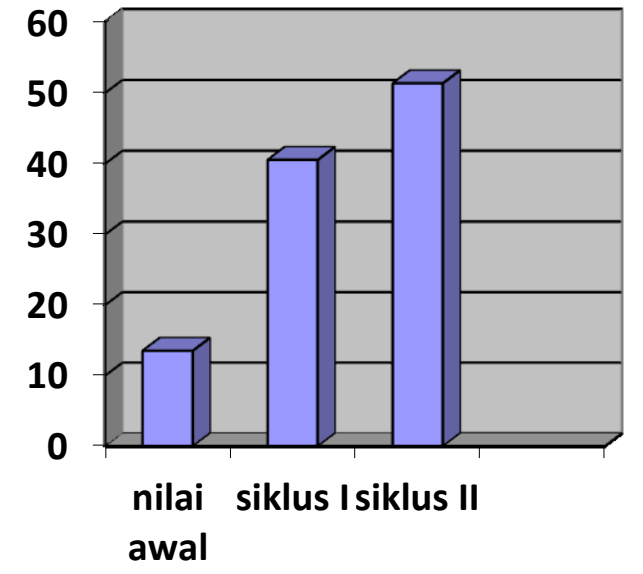

Gambar 4. Presentase ketuntasan hasil peserta didik

Berdasarkan tabel dan gambar grafik di atas menunjukkan bahwa presentase keberhasilan peserta didik mengalami peningkatan. Pada tes yang dilakukan sebelum tindakan diberikan (pretest), dari 32 peserta didik yang mengikuti, hanya ada 4 peserta didik yang mencapai ketuntasan belajar. Sedangkan setelah diterapkan media pembelajaran crorodile phyisc pada siklus I, dari 32 orang yang mengikuti tes akhir siklus I yang berupa terdapat 6 orang atau 18,75\% peserta didik yang mencapai ketuntasan belajar. Dengan demikian setelah dilakukan tindakan siklus I, hasil belajar peserta didik mengalami peningkatan sebesar $6,25 \%$.

\section{Siklus II}

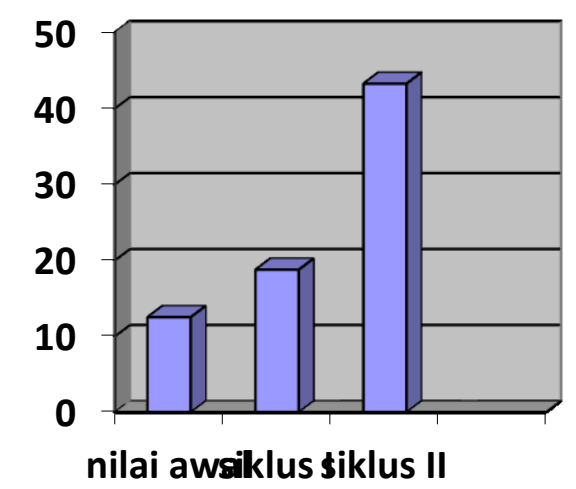

Gambar 5. Presentase ketuntasan hasil peserta didik

Berdasarkan tabel dan gambar grafik di atas menunjukkan bahwa presentase keberhasilan peserta didik mengalami peningkatan. Pada tes yang dilakukan pada post test siklus I, dari 32 peserta didik yang mengikuti, ada 6 peserta didik yang mencapai ketuntasan belajar. Sedangkan setelah dilakukan post test pada siklus II, dari 32 orang yang mengikuti tes akhir siklus II terdapat 16 orang atau 43,24\% peserta didik yang mencapai ketuntasan belajar. Dengan demikian setelah dilakukan tindakan siklus II, hasil belajar peserta didik mengalami peningkatan sebesar $24,49 \%$.

\section{Siklus III}

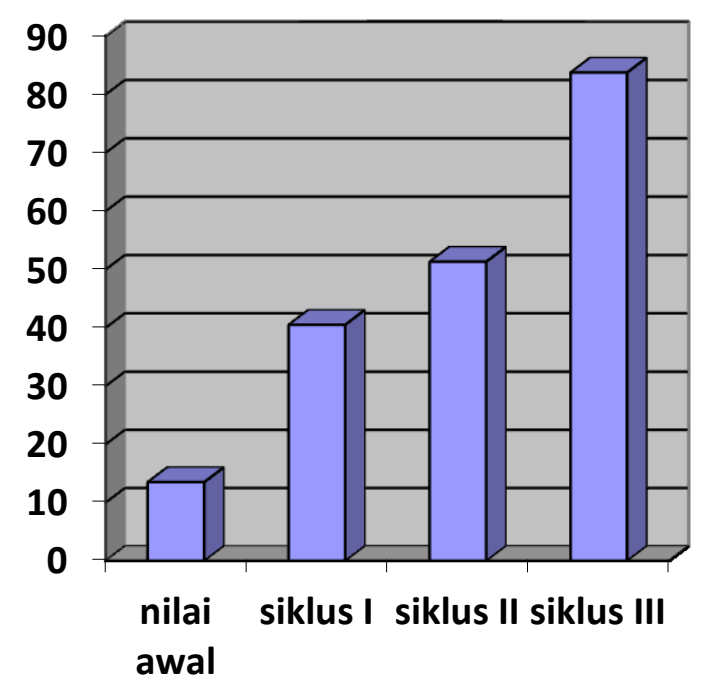

Gambar 6. Presentase ketuntasan hasil peserta didik

Berdasarkan tabel dan gambar grafik di atas menunjukkan bahwa presentase keberhasilan peserta didik mengalami peningkatan. Pada tes yang dilakukan pada post test siklus II, dari 37 peserta didik yang mengikuti, ada 19 peserta didik yang mencapai ketuntasan belajar. Sedangkan setelah dilakukan posttest pada siklus III, dari 37 orang yang mengikuti tes akhir siklus III terdapat 31 orang atau $83,78 \%$ peserta didik yang mencapai ketuntasan belajar. Dengan demikian setelah dilakukan tindakan siklus III, hasil belajar peserta didik mengalami peningkatan sebesar 32,43\% sehingga pada siklus ke III berhasil mencapai ketuntasan belajar. 


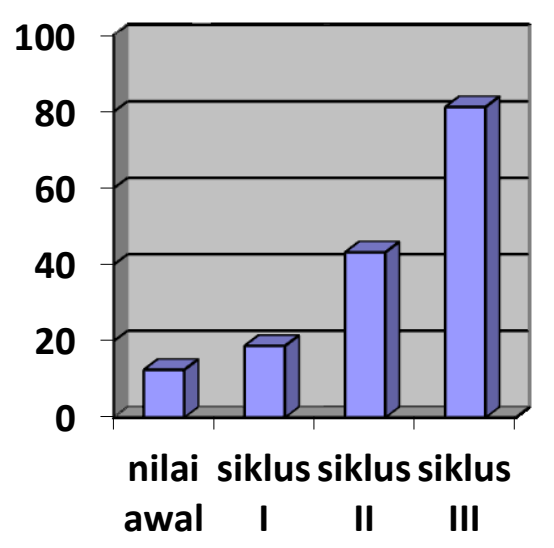

Gambar 7. Presentase ketuntasan hasil peserta didik

Berdasarkan tabel dan gambar grafik di atas menunjukkan bahwa presentase keberhasilan peserta didik mengalami peningkatan. Pada tes yang dilakukan pada post test siklus II, dari 32 peserta didik yang mengikuti, ada 16 peserta didik yang mencapai ketuntasan belajar. Sedangkan setelah dilakukan posttest pada siklus III, dari 32 orang yang mengikuti tes akhir siklus III terdapat 26 orang atau $81,25 \%$ peserta didik yang mencapai presentase ketuntasan belajar peserta didik. Dengan demikian setelah dilakukan tindakan siklus III, hasil belajar peserta didik mengalami peningkatan sebesar 38,01\% sehingga pada siklus ke III berhasil mencapai ketuntasan belajar.

Berdasarkan peningkatan hasil tindakan yang terjadi dari siklus ke siklus, maka peneliti merasa hasil ini sudah dapat digunakan untuk mengambil sebuah kesimpulan pada penelitian ini,terjadi perebedaan hasil pemahaman konsep pada kelas VIII I dan kelas VIII A,hal ini mungkin akibat adanya beberapa faktor yaitu : penguasaan materi siswa,fasilitas penunjang kelas dan keaktifan siswa bertanya kepada peneliti dan diskusi tentang rumusan masalah-masalah yang berkaitan dengan materi. Selain itu karena pokok bahasan yang diteliti telah selesai, maka penelitian dengan menerapkan media pembelajaran Crocodile Physics dalam meningkatkan pemahaman konsep fisika siswa di kelas VIII I di SMPN 1
Bandarlampung dan dikelas VIII A di SMPN 25 Bandarlampung pada pokok bahasan gelombang bunyi ini dinyatakan selesai.

\section{KESIMPULAN DAN SARAN}

Berdasarkan hasil analisa dan bahasan yang telah dikemukakan diatas dapat menyimpulkan bahwa media pembelajaran berupaCrocodile Physics dapat meningkatkan pemahaman konsep fisika siswa.

Beberapa hal yang penulis sarankan dari hasil penelitian diantaranya, dalam pembelajaran fisika khususnya pokok bahasan gelombang bunyi ada baiknya guru menggunakan media pembelajaran Crocodile Physics sebagai penunjang materi yang disampaikan, sehingga nantinya peserta didik merasa tidak jenuh dalam proses belajar dan menjadikan peserta didik aktif dalam pembelajaran dan menyimulasikan virtual lab nya.

\section{DAFTAR PUSTAKA}

Asyhari, A., \& Silvia, H. (2016). Pengembangan Media Pembelajaran Berupa Buletin dalam Bentuk Buku Saku untuk Pembelajran IPA Terpadu. Jurnal Ilmiah Pendidikan Fisika Al-Biruni, 5(1), 1.

Coghlan, D., \& Brannick, T. (2002). Doing Action Research In Your Own Organization (Second Edition). London: Taylor \& Francis e-library.

Gumrowi, A. (2017). Meningkatkan Hasil Belajar Listrik Dinamik menggunakan Strategi Pembelajaran Team Assisted Individualization melalui Simulasi Crocodile Physics. Jurnal Ilmiah Pendidikan Fisika AlBiruni, 5(1), 105. https://doi.org/10.24042/jpifalbiruni. v5i1.110

Komikesari, H. (2016). Peningkatan Keterampilan Proses Sains dan Hasil Belajar Fisika Siswa pada Model Pembelajaran Kooperatif Tipe 
Student Team Achievement Division. Tadris: Jurnal Keguruan Dan Ilmu Tarbiyah, 01(1), 15-22.

Lutfiyah, I. (2011). Perbedaan Hasil Belajar IPS dengan Menggunakan metode Pembelajaran Think Talk Write (TTW) dan Number Head Together (NHT) di SMP Islamiyah Ciputat.

Madya, S. (2011). Penelitian Tindakan (Action Research). Yogyakarta: Alfabeta.

Mills, G. E. (2003). Action Research: A Guide For The Teacher Researcher Second Edition. USA: library of congress cataloging in publica.

Mursalin. (2014). Meninimalkan Miskonsepsi Pada Materi Rangkaian Listrik Dengan Pembelajaran Predict-Observe-Explain. Jurnal Ilmu Pendidikan, 20(1).

R.K, L. . A. dan D. (2010). Kerangka Landasan untuk Pembelajaran, Pengajaran dan asesmen. Yogyakarta: Pustaka belajar.

Rofik, M. C., \& Basuki, I. (2015). Pengembangan Perangkat Pembelajaran Instalasi Penerangan Listrik Dengan Model Pembelajaran Kooperatif Tipe Marry Go Round (Keliling Kelompok) Di SMK Raden Fatah Mojokerto. Jurnal Pendidikan Teknik Elektro, 4(1).

Sadiqin, I. K., Santoso, U. T., \& Sholahuddin, A. (2017). Pemahaman Konsep IPA Siswa SMP Melalui Pembelajaran Problem Solving pada Topik Perubahan Benda-Benda di Sekitar Kita. Jurnal Inovasi Pendidikan IPA,3(1).

Santoso, R. B. (2013). Implementasi Model Pembelajaran Physic Eduitment Dengan Bantuan Media Crocodile Physic Pada Mata Pelajaran Fisika kelas $X$ di MAN 1 Kota Magelang.

Wajdi, B. (2015). Pemanfaatan Media Power Point Dalam Pembelajaran Fisika Dengan Pendekatan
Konstruktivisme. Jurnal Pendidikan Fisika Universitas Muhammadiyah Metro, 3(2).

Yuberti, Y. (2015). Online Group Discussion pada Mata Kuliah Teknologi Pembelajaran Fisika. Jurnal Ilmiah Pendidikan Fisika AlBiruni, 4(2). 